Araştırma Makalesi / Research Paper

\title{
Burdur-Gölhisar Yöresi Anadolu Karaçamı \\ [Pinus nigra Arnold. subsp. pallasiana (Lamb.) Holmboe] Popülasyonlarında Üreme x Büyüme Özellikleri Etkileşimi
}

\author{
Mahmut ÇERÇiOĞLU ${ }^{1}$, Nebi BíLíR ${ }^{2^{*}}$ \\ ${ }^{1}$ Mehmet Akif Ersoy Üniversitesi, Gölhisar Meslek Yüksekokulu, Burdur \\ ${ }^{2}$ Süleyman Demirel Üniversitesi, Orman Fakültesi, Isparta \\ Geliş Tarihi (Received): 16.02.2018, Kabul Tarihi (Accepted): 14.03.2018 \\ $\square$ Sorumlu Yazar (Corresponding author*): nebibilir@sdu.edu.tr \\ (C) $+902462113837 \quad$ 且 +902462373948
}

ÖZ

Çalışmada, Anadolu Karaçamı'nın [Pinus nigra Arnold. subsp. pallasiana (Lamb.) Holmboe] yükselti basamağına göre $(1300 \mathrm{~m}<, \leq 1300-1600 \mathrm{~m}<, 1600 \mathrm{~m} \leq)$ örneklenen, üç doğal popülasyon ve 270 bireyine ait iki yıllık (20152016) veriler ışığında, çiçek, kozalak ve tohum özellikleri ile büyüme özellikleri arasındaki ilişkilerin tahmin edilerek türün silvikültürel uygulamaları ile diğer ormancılık faaliyetlerine katkı sağlanması amaçlanmıştır. Uygulanan korelasyon analizi sonucunda üreme özellikleri arasında genel olarak istatistiksel bakımdan anlamlı $(p<0.05)$ pozitif ilişkiler belirlenirken; üreme özellikleri ile büyüme özellikleri ve yükselti arasındaki ilişkilerler yıl, popülasyon ve özelliğe göre değişim göstermiştir.

Anahtar Kelimeler: Boy, Çap, Çiçek, Korelasyon, Kozalak

\section{Interaction between Growth and Reproductive Characters of Anatolian Black Pine [Pinus nigra Arnold. subsp. pallasiana (Lamb.) Holmboe] Populations in Burdur-Gölhisar District}

\begin{abstract}
This study was carried out on 270 individual trees of three natural populations sampled altitudinal $(1300 \mathrm{~m}<$, $\leq 1300-1600 \mathrm{~m}<, 1600 \mathrm{~m} \leq$ ) for two years (2015-2016) of Anatolian Black Pine [Pinus nigra Arnold. subsp. pallasiana (Lamb.) Holmboe] to estimate interaction between growth and reproductive characters for contribution silvicultural and other forestry practices of the species. Significant $(p<0.05)$ and positive relations were found generally among reproductive characteristics, while the relations among altitude, growth and reproductive characters changed for years and populations, and also for characters based on results of correlation analysis.
\end{abstract}

Keywords: Height, Diameter, Strobili, Correlation, Cone 


\section{Giriş}

Karaçam (Pinus nigra Arn.); batıda Fas ve İspanya, doğuda Türkiye, güneyde Kıbrıs, kuzeyde de Kırım Ukrayna ve Avusturya arasında doğal yayılış gösteren bir orman ağacı türüdür (Atalay ve Efe, 2012). Bu tür, Pinus nigra Arnold. subsp. nigra (Avusturya karaçamı), Pinus nigra Arnold. subsp. larico (Poiret) Maire (Korsika karaçamı), Pinus nigra Arnold. subsp. dalmatica (Vis.) Franco (Dalmaçya karaçamı), Pinus nigra Arnold. subsp. salzmannii (Dunal) Franco (Pirene karaçamı), Pinus nigra Arnold. subsp. pallasiana (Lamb.) Holmboe (Anadolu karaçamı) olmak üzere beş alt türe ayrılmaktadır. Çalışmaya konu Anadolu karaçamının ise 5 varyetesi bulunmaktadır: Pinus nigra subsp. Pallasiana var. pallasiana, Pinus nigra subsp. Pallasiana var. şeneriana, Pinus nigra subsp. Pallasiana var. yaltirikiana, Pinus nigra subsp. pallasiana var. columnaris-pendula var. nova, Pinus nigra subsp. pallasiana var. pyramidata'dır (Gaussen ve ark., 1964; Alptekin, 1986; Yaltırık, 1993). Ülkemizde bölgesel olarak yayılışında; Trakya, Ege, Marmara, İç ve Doğu Anadolu'da, Karadeniz de ise yeşil ırmağın batısında bulunur (Anonim, 2017). Gerek 4,7 milyon hektar büyüklüğündeki geniş doğal yayılış alanı ve gerekse ekonomik değeri bakımından önde gelen doğal orman ağacı türlerimizden olan Anadolu Karaçamı ormanlarının \%45'i, bozuk orman niteliğindedir (Anonim, 2017) ve uygun silvikültürel müdahalelerle verimli hale dönüştürülmeyi beklemektedir. Bu silvikültürel müdahalelerin belirlenmesi ve uygulamaya aktarılmasında üremexbüyüme özellikleri etkileşiminin tahmini önemli rol oynamaktadır.

Burdur-Gölhisar yöresindeki doğal Anadolu Karaçamı popülasyonlarında, büyüme ve iki yıllık üreme özellikleri ile gerçekleştirilen bu çalışmayla üremexbüyüme özellikleri etkileşimi bağlamında, türün tohum meşçerelerinin seçimine; tohum teknolojisine; genetik-ıslah çalışmaları ile diğer muhtemel silvikültürel uygulamalarına katkı sağlanması amaçlanmıştır.

\section{MATERYAL VE YÖNTEM}

Çalışmada materyal olarak Gölhisar Orman İşletme Müdürlüğü'ne bağlı İbecik Orman İşletme Şefliği sınırları içerisinde kalan doğal Anadolu Karaçamı meşçereleri kullanılmıştır (Şekil 1).

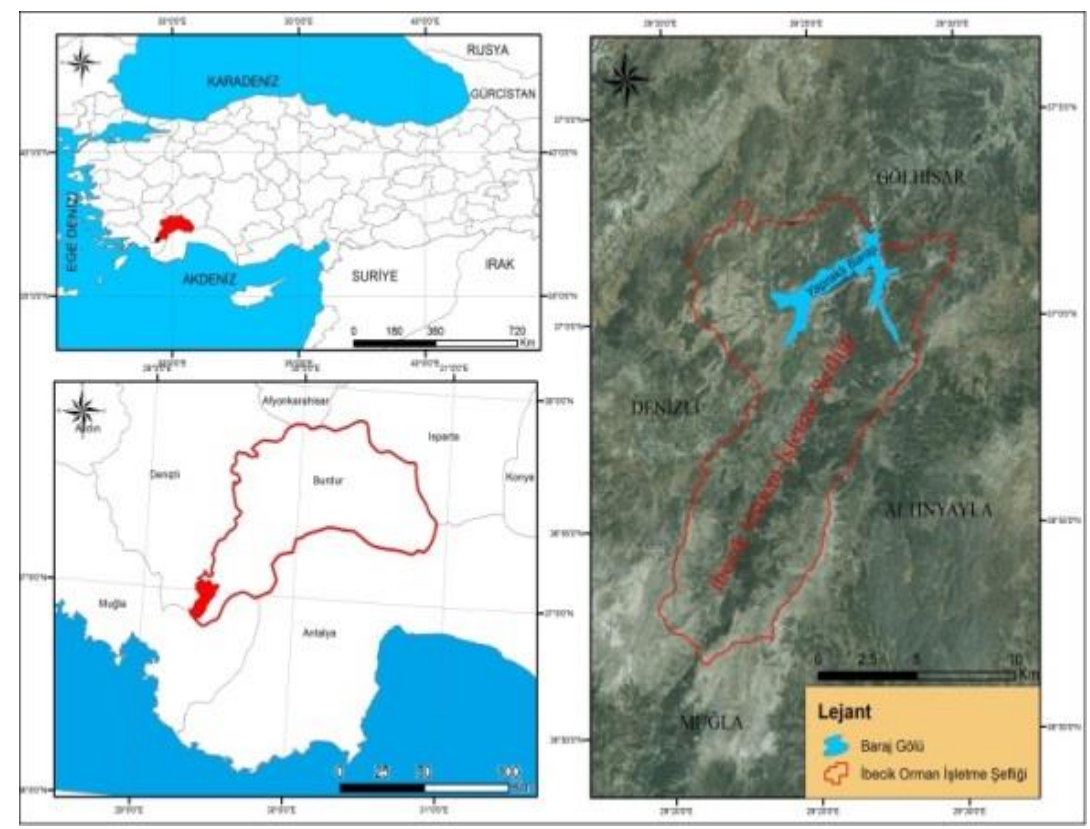

Şekil 1. Burdur-Gölhisar İbecik lokasyon haritası

Türün yöredeki doğal yayılış alanı 1300 metreden aşağı; 1300-1600 arası ve 1600 metreden yukarı olmak üzere üç yükselti $(\mathbf{R})$ basamağına ayrılmış ve yükselti içi örnekleme farklılığının 150 metreyi geçmemesine özen gösterilmiştir (Tablo 1). Her yükselti basamağın- dan en az 30 metre aralıkla fenotipik özellikler (boy, çap, gövde düzgünlügü, dallanma durumu; Zobel ve Talbert, 1984) dikkate alınarak 90'ar birey örneklenmiştir (Şekil 2-4). Böylece çalışma 270 aile üzerinde gerçekleştirilmiştir. 
Tablo 1. Çalışmaya konu popülasyonların genel coğrafik özellikleri

\begin{tabular}{cccccc}
\hline Kodu & Popülasyon & Enlem & Boylam & Yükselti (m) & Bakı \\
\hline ALT & $1300 \mathrm{~m} .<$ & $37^{\circ} 01^{\prime} 16^{\prime \prime}$ & $29^{\circ} 22^{\prime} 08^{\prime \prime}$ & 1196 & Bütün bakılar \\
ORTA & $\leq 1300-1600 \mathrm{~m} .<$ & $36^{\circ} 56^{\prime} 44^{\prime \prime}$ & $29^{\circ} 26^{\prime} 18^{\prime \prime}$ & 1472 & Güneydoğu \\
ÜST & $1600 \mathrm{~m} . \leq$ & $36^{\circ} 56^{\prime} 36^{\prime \prime}$ & $29^{\circ} 23^{\prime} 87^{\prime \prime}$ & 1708 & Bütün bakılar \\
\hline
\end{tabular}

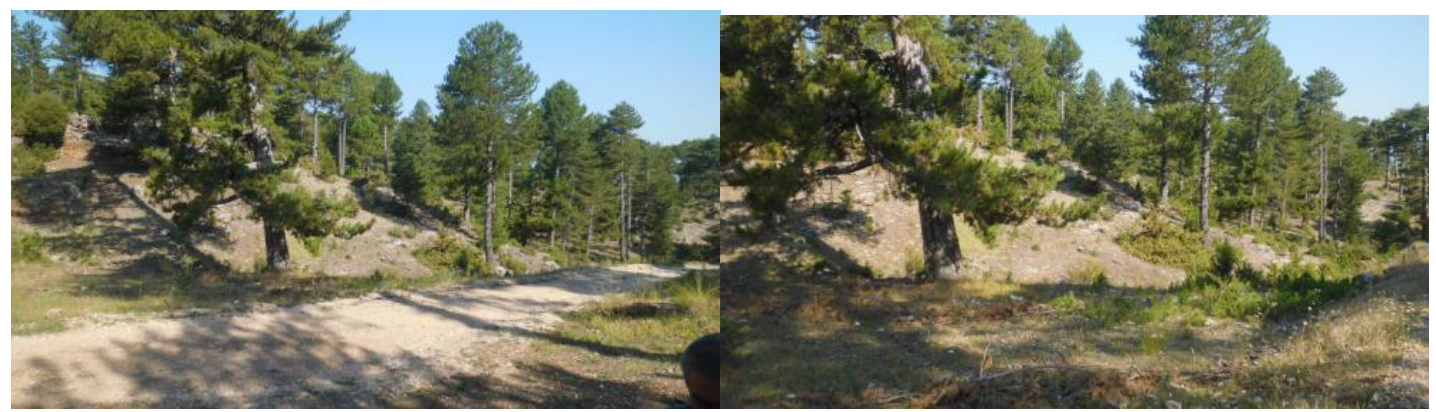

Şekil 2. 1300 metre altı örneklenen popülasyondan görünümler
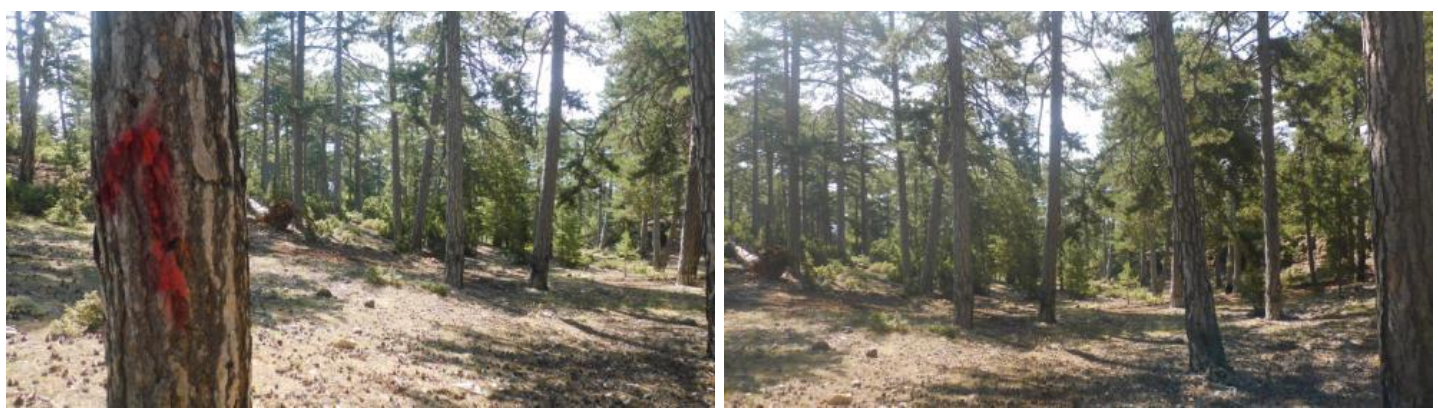

Şekil 3. 1300-1600 metreler arası örneklenen popülasyon
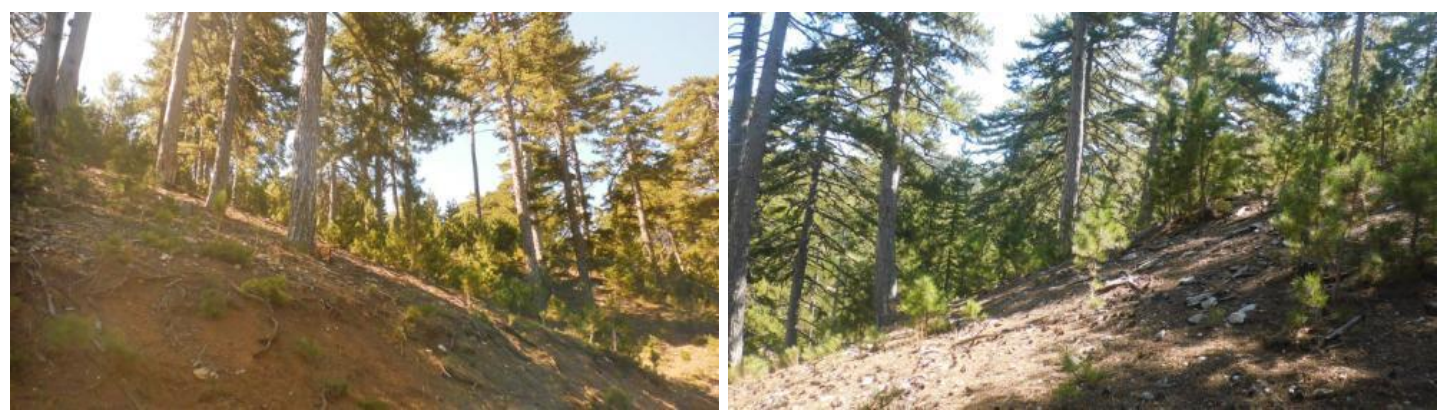

Şekil 4. 1600 metre üstünde örneklenen popülasyondan görünümler

Kozalak ve tohum verimliliği üzerinde doğrudan etkili olduğu düşünülen 2015 yılı aşağıdaki büyüme ve coğrafik özellikleri ile üreme özellikleri 2015 ve 2016 yılı sonbaharında ayrı ayrı tespit edilmiştir:

Boy (B): Toprak seviyesinden tepe tomurcuğu ucuna kadar olan mesafe olup boy ölçer (Haglöf-Vertex) yardımıyla $5 \mathrm{~cm}$ hassasiyette vejetasyon dönemi sonunda ölçülmüştür.
Göğüs yüksekliği çapı (d1.30): Göğüs yüksekliğindeki çap olup dönemsel olarak ve kumpas yardımıyla, vejetasyon dönemi sonunda ölçülmüştür.

Taç çapı (TÇ): Bireyin kuzey-güney ve doğu-batı yönlerindeki tepe izdüşümünün çapı olup, şeritmetre yardımıyla $5 \mathrm{~cm}$ hassasiyette vejetasyon dönemi sonunda ölçülmüştür. 
Yaş (Y): Göğüs çapı ölçümü yapılan noktada, bir birine çapraz alınacak iki artım kalemi verilerinin ortalaması olarak tahmin edilmiştir.

Çiçek ve kozalak sayımı: Erkek (Çđ) ve dişi (Çㅇ) çiçek sayımı, önceden belirlenen popülasyon ve numaralandırılmış bireyler üzerinde 2016 ve 2017 yılları ilkbaharında yapılmıştır. Numaralandıran bireylerde 2015 ve 2016 yılları sonbaharında olgunlaşmış toplam kozalaklar (normal büyüklükte, karpelleri kapalı veya kısmen açık, gri kahverengi iki yıllık kozalak birey bazında sayılmıştır (KS).

Kozalak hasadı ve tohum verimi ile özellikleri: Aile ve popülasyonu en yüksek oranda temsil etmesi için, her bir bireyin kuzey, güney, doğu ve batı yönlerinin, alt, orta ve üst kısmından birer adet olmak üzere, her bir bireyden 12 kozalak, bireyde yeterli sayıda kozalak olmaması durumunda her bir yönden bir olmak üzere en az dört kozalak 2015 ve 2016 yılları sonbaharında hasat edilmiştir.

Hasat edilen kozalaklar, popülasyon ve aile bazında ayrı ayrı numaralandırılarak laboratuvar ortamına getirilmiş ve kozalaklarda boy (KB), en (KE) ve ağırlık (KA) ölçümleri gerçekleştirilmiştir.

Ölçümü tamamlanan kozalaklardan tohumlar hasat edilerek popülasyon ve aile bazında dolu tohum sayımı (TS) yapılmıştır. Böylece, her bir kozalaktaki ortalama dolu tohum sayısı tespit edilmiş ve kozalak sayısından hareketle de her bir aile için ortalama dolu tohum sayısı hesaplanmıştır. Sayımı tamamlanan tohumlarda boy (TB), en (TE) ve ağırlık (TA) ölçümleri gerçekleştirilmiş- tir (Şekil 3.10). Bu sayım ve ölçümler iki yıl tekrarlanmiştır.

Elde edilen verilerde; temel istatistiksel değerler yanında, çalışmaya konu özellikler bakımından popülasyon içi ve popülasyonlar arası karşılaştırmalar, aşağıdaki varyans analizi (MANOVA) modeli ile SPSS paket programında uygulanmıştır (Özdamar, 1999).

$$
Y_{i_{j k}}=\mu+P_{i}+S_{j}+P(S)_{i(j)}+e_{i j k}
$$

Burada $Y_{i j k}$, i. popülasyonun j. yıldaki k. ailesine ait değerini; $\mu$, genel ortalamayı; $P_{i}$, j. yıldaki i. popülasyonun etkisini; $S_{j}$, j. yılın etkisini; $P(S)_{i(j)}$ popülasyon ile yıl etkileşimini; $e_{\mathrm{ijk}}$ ise hatayı göstermektedir.

Büyüme özellikleri (boy, göğüs yüksekliği çapı, yaş, tepe tacı) ile kozalak ve tohum özellikleri arasındaki ilişkileri belirlemek amacıyla Pearson'un korelasyon analizi ile uygulanmıştır.

\section{BULGULAR VE TARTIŞMA}

\section{Büyüme Özellikleri}

Üreme özellikleri üzerinde doğrudan veya dolaylı etkili olduğu düşünülen büyüme özellikleri 2015 yılı büyüme dönemi sonunda ölçülmüş ve yükselti basamağına göre örneklenen popülasyonların büyüme özelliklerine ilişkin ortalama ve minimum-maksimum değerleri Tablo 2'de verilmiştir. Tablo 2'den de görüldüğü üzere popülasyonlar büyüme özellikleri bakımından benzer ortalama değerlere sahiptir.

Tablo 2. Ortalama ve minimum-maksimum büyüme özellikleri değerleri

\begin{tabular}{ccccccc}
\hline \multirow{2}{*}{ Özellikler } & \multicolumn{2}{c}{ ALT } & \multicolumn{2}{c}{ ORTA } & \multicolumn{2}{c}{ ÜST } \\
& Ort. & Min - Mak. & Ort. & Min - Mak. & Ort. & Min - Mak. \\
\hline B $(\mathrm{m})$ & 21.0 & $18.0-24.0$ & 19.0 & $17.0-21.0$ & 21.0 & $18.0-25.0$ \\
$\mathbf{d}_{1.30}(\mathrm{~cm})$ & 44.5 & $37.0-51.0$ & 44.1 & $37.0-51.0$ & 44.0 & $37.0-51.0$ \\
TÇ $(\mathrm{cm})$ & 506.0 & $330.0-715.0$ & 498.0 & $330.0-665.0$ & 627.0 & $400.0-800.0$ \\
Y (yIl) & 74 & $65-82$ & 74 & $64-84$ & 73 & $62-80$ \\
\hline
\end{tabular}

Popülasyonların büyüme özellikleri bakımından karşılaştırılması amacıyla uygulanan varyans analizi sonucunda boy ve taç çapı bakımından popülasyonlar arasında anlamlı farklılıklar $(p<0.05)$ ortaya çıkmıştır.

Popülasyonlardaki ailelerin gerek ortalama ve gerekse minimum yaşlarına bakıldığında, tamamının tohum verme yaşında olduğu görülmektedir (Tablo 2). Zira, orman ağacı türlerinde tohum verme yaşı, yetişme ortamı özelliklerine ve ağaçların tepe gelişimine göre değişmekle birlikte örneğin, Kızılçam'da 20, Sarıçam ve Karaçam'da 30, Sedir türlerinde 40, Ladin türlerinde 50 ve Göknar türlerinde 60 olarak bilinmektedir (Anonim, 1986).

\section{Üreme Özellikleri}

Popülasyonlarda ve dolayısıyla yükselti basamakları içi ve arası, dişi ve erkek çiçek verimi bakımından geniş farklılıklar görülmektedir (Tablo 3). Örneğin, 2015 yılında en düşük dişi çiçek verimine sahip (32) alt yükselti basamağı, 2016 yılında en yüksek dişi çiçek üreten (181) yükselti basamağı olmuştur. Bununla birlikte çiçek verimi bakımından aynı yükselti basamağındaki 
aileler arası da geniş farklılıklarda söz konusudur (Tab- lo 3).

Tablo 3. Popülasyonlarda ortalama ve minimum-maksimum çiçek sayıları

\begin{tabular}{|c|c|c|c|c|c|c|}
\hline \multirow[b]{2}{*}{ Özellikler } & \multicolumn{2}{|c|}{ ALT } & \multicolumn{2}{|c|}{ ORTA } & \multicolumn{2}{|c|}{ ÜST } \\
\hline & Ort. & Min - Mak. & Ort. & Min - Mak. & Ort. & Min - Mak \\
\hline & & & 2015 & & & \\
\hline $\begin{array}{l}\text { Ç} \\
\text { Ç}\end{array}$ & $\begin{array}{c}32 \\
321\end{array}$ & $\begin{array}{c}8-55 \\
80-500 \\
\end{array}$ & $\begin{array}{c}89 \\
268 \\
\end{array}$ & $\begin{array}{l}27-165 \\
80-500\end{array}$ & $\begin{array}{l}111 \\
336 \\
\end{array}$ & $\begin{array}{c}33-180 \\
100-500\end{array}$ \\
\hline & & & 2016 & & & \\
\hline $\begin{array}{l}\text { Ç} \\
\text { Ç}\end{array}$ & $\begin{array}{l}181 \\
536\end{array}$ & $\begin{array}{l}20-400 \\
60-1200\end{array}$ & $\begin{array}{c}55 \\
165\end{array}$ & $\begin{array}{c}3-130 \\
10-400\end{array}$ & $\begin{array}{c}69 \\
206\end{array}$ & $\begin{array}{c}3-165 \\
10-500\end{array}$ \\
\hline
\end{tabular}

Çiçek verimi bakımından Tablo 3'te verilen geniş farklılıklar, uygulanan varyans analizi ile de desteklenmiş ve varyans analizi sonucunda çiçek verimi bakımından popülasyonlar yani yükselti basamakları ile yıllar arası istatistiksel anlamlı farklılık $(p<0.05)$ ortaya çıkmıştır. Bununla birlikte yılxpopülasyon etkileşiminin istatistiksel bakımdan önemli olduğu $(p<0.05)$ belirlenmiştir. Bu farklılığın belirlenmesiyle uygulanan Duncan testi bakımından yükselti kademeleri dişi çiçek verimi bakımından beş homojen grup oluştururken, erkek çiçek verimi bakımından dört homojen grup oluşturmuştur. Ancak, ilgili Duncan testi sonucunda alt yükselti basamağının çiçek verimi bakımından alt yükselti basamağının genel olarak diğerlerinden farklılık göstermiştir. Bu sonuçlar türde popülasyonlar arasında ve popülasyon içi bireyler arasında üreme verimi bakımından geniş farklılıklar olabileceğini göstermektedir ve bu sonuçlar türün seleksiyon çalışmaları ile tohum kaynaklarının idaresinde önem arz etmektedir.

Bilir ve Özel (2017a) aynı türün tohum bahçesi üzerinde gerçekleştirmiş oldukları çalışmada dişi ve erkek çiçek sayılarını sırasıyla 145 ve 706 bulmuşlardır. Aynı türün bir başka tohum bahçesinde gerçekleştirilen çaıışmada dişi ve erkek çiçek sayılarını sırasıyla 78 ve
187 bulunmuştur (Bilir ve ark., 2002). Uysal (2015) tarafından Isparta-Gönen Karaçam tohum bahçesinde gerçekleştirilen çalışmada klonlarda, 2012 yılı ortalamalarına göre erkek çiçek kurulu sayısı 93, erkek çiçek sayısı 1222, dişi çiçek sayısı 273 adet; 2013 yılı ortalamalarına göre ise erkek çiçek kurulu sayısı 177; erkek çiçek sayısı ise 2889; dişi çiçek sayısı 258 adet bulmuştur. Değişik orman ağacı türlerinin doğal veya yapay popülasyonlarında bireyler arası ile (Griffin, 1982; Shea, 1987; Xie ve Knowles, 1992; El-Kassaby, 1995; Bila, 2000; Kang ve ark., 2003; Bilir ve ark., 2005; Bilir ve Özel, 2017b) tohum bahçelerinde klonlar arası (Kjaer, 1996; Bila ve Lindgren, 1998; Kang ve Lindgren, 1998; Bila ve ark., 1999; Keskin, 1999; Nikkanen ve Ruotsalainen, 2000; Almqvist ve ark., 2001; Bilir ve ark., 2002) geniş çiçek verimi varyasyonu belirlenmiş olup bu sonuçlar çalışma sonuçları ile uyum göstermektedir. Bu sonuçlar genetik-ıslah çalışmalarında seleksiyonun önemini bir kez daha vurgulamaktadır.

Çalışmaya konu kozalak özelliklerinden sayısı (KS), boy (KB), en (KE) ve ağırlığına (KA) ilişkin ortalama ve standart sapma değerleri popülasyon ve yıllara göre Tablo 4'te verilmiştir.

Tablo 4. Kozalak özelliklerine ilişkin ortalama ve standart sapma değerleri

\begin{tabular}{|c|c|c|c|c|c|c|}
\hline \multirow[b]{2}{*}{ Özellikler } & \multicolumn{2}{|c|}{ ALT } & \multicolumn{2}{|c|}{ ORTA } & \multicolumn{2}{|c|}{ ÜST } \\
\hline & Ort. & St. sapma & Ort. & St. sapma & Ort. & St. sapma \\
\hline & & & 2015 & & & \\
\hline KS & 119 & 76.79 & 91 & 45.5 & 107 & 68.49 \\
\hline $\mathrm{KB}(\mathrm{mm})$ & 67.6 & 2.43 & 56.6 & 3.15 & 73.1 & 3.41 \\
\hline $\mathrm{KE}(\mathrm{mm})$ & 33.6 & 2.79 & 27.9 & 1.39 & 34.4 & 2.38 \\
\hline$K A(g)$ & 41.8 & 2.07 & 33.9 & 1.66 & 43.2 & 2.67 \\
\hline & & & 2016 & & & \\
\hline KS & 87 & 55.77 & 61 & 49.55 & 67 & 44.04 \\
\hline $\mathbf{K B}(\mathrm{mm})$ & 67.5 & 2.40 & 56.6 & 3.17 & 73.0 & 3.39 \\
\hline $\mathrm{KE}(\mathrm{mm})$ & 33.5 & 2.75 & 27.8 & 1.41 & 34.3 & 2.35 \\
\hline $\mathrm{KA}(\mathrm{g})$ & 41.7 & 2.09 & 33.8 & 1.69 & 43.1 & 2.55 \\
\hline
\end{tabular}

Kozalak sayısı bakımından her iki yılda da alt yükselti basamağı en yüksek değeri (119 ve 87) gösterirken, kozalak boyutu ve ağırlığı bakımından üst yükselti basamağı daha yüksek değerlere sahiptir (Tablo 4). Uygulanan varyans analizi sonucunda çalışmaya konu kozalak özellikleri bakımından popülasyonlar/yükselti basamakları ile yıllar arası istatistiksel anlamlı farklılık $(p<0.05)$ ortaya çıkarken bu özellikler bakımından yılxpopülasyon etkileşiminin istatistiksel bakımdan önemli olmadığı $(p>0.05)$ belirlenmiştir. Varyans analizi sonucunda çalışmaya konu kozalak özellikleri bakımından yükselti basamakları ve yıllar arası istatistiksel 
anlamlı farklılık $(p<0.05)$ belirlenmesiyle, uygulanan Duncan testi sonucunda yükselti basamakları ve yılların kozalak sayısı bakımından diğer kozalak özelliklerine göre daha heterojen bir yapı gösterdiği ortaya çıkmıştır. Yıllar itibariyle kozalak verimi farklıığı aynı türün tohum bahçesinde gerçekleştirilen çalışmada üç yıllık veriler ışığında da belirlenmiştir (Bilir ve Özel, 2017a). Orman ağaçları biyolojileri gereği enerjilerini bazı dönemlerde büyümeye bazı dönemlerde de üremeye harcamaktadır (Kang, 2001). Bu nedenle yıllar arası üreme verimi farklılıkları beklenen olgulardandır. Bununla birlikte ülkemiz koşullarında Karaçam'ın bol tohum yılları, düşük rakımlarda ve güneyli bakılarda iki yılda bir, yüksek rakımlarda ve kuzeyli bakılarda ise üç yılda bir görülmektedir (Saatçioğlu, 1971; Ata, 1995). Bu düşüncelerde, çalışma sonuçlarını desteklemektedir ve türdeki tohum hasat yılının önemini vurgulamaktadır. Kozalak verimi bakımından popülasyon içi ve popülasyon arası geniş kozalak verimi farklılıkları değişik orman ağacı türlerinde de belirlenmiştir (Ülküdür, 2013; Çerçioğlu, 2013; Keleş, 2015; Bilir, 2017; Bilir ve Özel, 2017b; Yazıcı ve Bilir, 2017). Örneğin, Toros Göknarı'nın (Abies cilicica Carr.) rakımsal olarak örneklenen üç popülasyonunda $(1500 \mathrm{~m}>$; $1500 \mathrm{~m} \leq-1750 \mathrm{~m} \geq$; $1750 \mathrm{~m}<$ ) kozalak verimi bakımından popülasyonlar arası ve popülasyon içi geniş farklılıklar bulunmakla birlikte, ortalama kozalak verimi 6,7 adet belirlenmiş ve kozalak verimi bakımından, düşük rakım ile yüksek rakım arasında yaklaşık 3 kat fark görülmüş ve kozalak verimi en yüksekten düşüğe doğru, alt-orta ve yüksek şeklinde sıralanmıştır (Ülküdür, 2013). On Sarıçam ve yedi Karaçam orijininde yapılan bir çalışmada, Sarıçam'da kozalak sayısının hektarda 14200-66250; Karaçam'da kozalak sayısının 26387-68175 arasında değiştiği belirlenmiştir (Ürgenç, 1967). Aynı çalışmada Sarıçam'ın Araç orijininin genç meşceresinde 14950 ve yaşlı meşceresinde 55150 adet kozalak saptanmıştır. Çalışmaya konu Karaçam'ın tohum bahçesinde gerçek- leştirilen çalışmada üç yıllık rametlerde ortalama kozalak sayısı 73 bulunmuş ve bu değerin yıllar itibariyle 4782 arasında değiştiği belirlenmiştir (Bilir ve Özel, 2017a). Türün tohum bahçesinde gerçekleştirilen bir çalışmada, kozalak eninin $30.73 \mathrm{~mm}$ ile $33,74 \mathrm{~mm}$, kozalak boyunun $61,48 \mathrm{~mm}$ ile $70.84 \mathrm{~mm}$, kozalak ağırlığının da 23.02 gr ile 30,07 gr arasında değiştiğini belirlemiştir (Uysal, 2015). Keçiboynuzunda yapılan çaIışmada, meyve özellikleri bakımından popülasyonlar ve yıllar arası farklılık popülasyon içinde de görülmekte olup, yıllar arasında meyve ağırlığı bakımından yaklaşık altı kat, meyve sayısı bakımından ise yaklaşık yedi kat farklılık söz konusudur (Keleş, 2015). Üç Halep Çamı (Pinus halepensis Mill.) ağaçlandırma sahasında gerçekleştirilen çalışmada, en düşük kozalak verimine sahip birey ile en yüksek kozalak verimine sahip aile arasında, P1 popülasyonunda (10-400) 40 kat, P2 popülasyonunda (12-335) 30 kat ve $\mathrm{P} 3$ popülasyonunda (10-250) 25 kat farklılık belirlenirken; popülasyonlar arasında bu farklılık yaklaşık \%50 olarak belirlenmiştir (Çerçioğlu, 2013). Kozalak verimi bakımından yıllar arası değişimler, büyük ölçüde ağaç türünün genetik özelliklerine ve çevresel faktörlere bağlı olabilir. Bununla birlikte çevre faktörlerinin üreme özellikleri üzerine olan etkisi birçok çalışma ile belirlenmiştir (Boydak, 1977; Koski, 1991; Mátyás, 1991; Eriksson, 2008). Gerek bu tez çalışması ve gerekse önceki çalışmalarda elde edilen sonuçlar popülasyonlar arası üreme verimi farklılığının olağan olduğunu göstermekle birlikte bu sonuçlar tohum kaynaklarının seçimi gibi genetik-ıslah çalışmaları ile diğer ormancılık faaliyetleri için önem arz etmektedir.

Çalışmaya konu tohum özelliklerinden sayı (TS), boy (TB), en (TE) ve ağırlığa (TA) ilişkin ortalama ve standart sapma değerleri popülasyon ve yıllara göre Tablo 5 'te verilmiştir.

Tablo 5. Tohum özelliklerine ilişkin ortalama ve standart sapma değerleri

\begin{tabular}{|c|c|c|c|c|c|c|}
\hline \multirow[b]{2}{*}{ Özellikler } & \multicolumn{2}{|c|}{ ALT } & \multicolumn{2}{|c|}{ ORTA } & \multicolumn{2}{|c|}{ ÜST } \\
\hline & Ort. & St. sapma & Ort. & St. sapma & Ort. & St. sapma \\
\hline & & & 2015 & & & \\
\hline TS & 6092 & 3970.8 & 4280 & 2422.6 & 5526 & 3518.6 \\
\hline TB $(\mathrm{mm})$ & 7.0 & 0.3 & 6.8 & 0.4 & 8.2 & 0.7 \\
\hline TE (mm) & 3.6 & 0.6 & 3.6 & 0.6 & 4.2 & 0.0 \\
\hline TA (g/agaç) & 822.5 & 536.1 & 535.1 & 302.8 & 828.9 & 527.8 \\
\hline & & & 2016 & & & \\
\hline TS & 649 & 601.9 & 309 & 353.3 & 1045 & 980.2 \\
\hline TB (mm) & 7.0 & 0.3 & 6.8 & 0.4 & 8.2 & 0.1 \\
\hline TE $(\mathrm{mm})$ & 3.6 & 0.7 & 3.6 & 0.5 & 4.2 & 0.1 \\
\hline TA (g/agaç) & 84.4 & 78.3 & 37.1 & 42.4 & 146.3 & 137.2 \\
\hline
\end{tabular}

Tohum verimi bakımından yükseklik kademeleri yüksekten düşüğe doğru 2015 yılında Alt-Üst-Orta; 2016 yılında ise üst-alt-orta şeklinde sıralanmıştır. Dolayısıyla her iki yılda da orta yükselti basamağı tohum sayısı bakımından en düşük performansı göstermiştir (Tablo 5). Tohum boyut ve ağırığı bakımından ise yine orta yükselti basamağı en düşük değerlere sahiptir. Yükselti 
basamakları içi ve arası tohum özellikleri bakımından geniş farklıııklar görülmektedir (Tablo 5).

Tohum özellikleri bakımından belirlenen geniş farklılıklar (Tablo 5) uygulanan varyans analizi ile de desteklenmeye çalışılmıştır ve uygulanan varyans analizi sonucunda; çalışmaya konu tohum özellikleri bakımından popülasyonlar/yükselti basamakları ile yıllar arası istatistiksel anlamlı farklılık $(p<0.05)$ ortaya çıkarken bu özellikler bakımından yılxpopülasyon etkileşiminin istatistiksel bakımdan önemli olmadığı $(p>0.05)$ belirlenmiştir. Uygulanan Duncan testi sonucunda ise, yükselti basamakları ve yılların tohum ağırlığı bakımından diğer tohum özelliklerine göre daha heterojen bir yapı gösterdiği söylenebilir. 10 Sarıçam ve 7 Karaçam orijininde yapılan bir çalışmada, Sarıçam'da tohum sayısının hektarda 314800-888400 arasında; Karaçam ise 422200-2908000 arasında değiştiği belirlenmiştir (Ürgenç, 1967). Uysal (2015) tarafından Karaçam tohum bahçesinde gerçekleştirilen çalışmada, tohum boyunun $6.68 \mathrm{~mm}$ ile $7.75 \mathrm{~mm}$, tohum eninin $4.36 \mathrm{~mm}$ ile 4.88 $\mathrm{mm}$, bir kozalaktaki ortalama tohum sayısının 24 ile 39 , bir kozalaktaki ortalama dolu tohum sayısının ise 14 ile 25 arasında değiştiğini belirlemiştir. Toros sediri'nde gerçekleştirilen bir çalışmada gerek aynı bireydeki kozalaklar arasında ve gerekse popülasyon içi bireyler arasında tohum verimi bakımından geniş farklııklar belirlenmiştir (Bilir ve Özel, 2017b).

Tohum boyut ve ağırlığı bakımından ise yine orta yükselti basamağı en düşük değerlere sahiptir (Tablo 5). Genetik çeşitliliği ve dolayısıyla ailelerin gelecek generasyonlardaki temsilini önemli düzeyde etkileyen ortalama tohum sayısı değerleri 2015 yılında 2016 yılına göre her üç yükselti basamağında da daha yüksek bulunmuştur. Bununla birlikte, tohum boyutu ve ağırlığı bakımından orta yükselti basamağı alt ve orta yükselti basamağına oranla daha düşük değerlere sahiptir (Tablo 5). Tohum özellikleri bakımından belirlenen geniş farklılıklar (Tablo 5), varyans analizi ile de desteklenmiş ve çalışmaya konu tohum özellikleri bakımından popülasyonlar/yükselti basamakları ile yıllar arası istatistiksel anlamlı farklılık $(p<0.05)$ ortaya çıkarken bu özellikler bakımından yılxpopülasyon etkileşiminin istatistiksel bakımdan önemli olmadığı $(p>0.05)$ belirlenmiştir. Bu özellikler için uygulanan Duncan testi sonucunda yükselti basamakları ve yılların tohum ağırlığı bakımından diğer tohum özelliklerine göre daha heterojen bir yapı göstermiştir.

\section{Özellikler Arasındaki İlişkiler}

Çiçek verimi, tohum ve kozalak özellikleri arasındaki ilişkilerin yıllara göre belirlenmesiyle amacıyla uygula- nan korelasyon analizi sonucunda üreme özellikleri arasında genel olarak istatistiksel bakımdan anlamlı $(p<0.05)$ pozitif ilişkiler belirlenmiştir (Şekil 5).

Şekil 5'ten de görüldüğü üzere 2015 yılı dişi ve erkek çiçek sayısı arasında ( $r=0.57), 2016$ yılı dişi ve erkek çiçek sayısı arasında ( $r=0.99)$, tohum sayısı $(r=0.28)$, ile kozalak sayısı $(r=0.48)$, bakımından yıllar arasında istatistiksel bakımdan çiçek sayıları arasında istatistiksel bakımdan anlamlı $(p<0.05)$ ilişkiler ortaya çıkmıştır. Çalışmaya konu Karaçam'ın Isparta-Gönen tohum bahçesinde gerçekleştirilen çalışmada, tepe tacı hacmi, dal uzunluğu, boy ve çap gibi büyüme karakterleri ile 2012 ve 2013 yılı erkek çiçek sayıları, erkek çiçek kurulu sayıları, dişi çiçek sayıları, kozalak sayısı ve diğer büyüme karakterleri arasında pozitif ve yüksek genetik korelasyonlar tahmin edilmiştir (Uysal, 2015). Ülkemizdeki Karaçam, Kızılçam ve Sarıçam üzerinde yapılan çalışmalarda da dişi ve erkek çiçek verimi arasında istatistiksel bakımdan anlamlı $(p<0.05)$ pozitif ilişkiler belirlenmiştir (Bilir ve ark., 2002). Keleş (2015) Keçiboynuzu popülasyonları üzerinde gerçekleştirmiş olduğu Doktora tez çalışmasında iki yıllık veriler ışığında meyve ve tohum özellikleri arasındaki ilişkilerin popülasyon, yıl ve özelliklere göre değişim gösterdiğini belirlemiş; tohum ve meyvenin ağırlık ile sayıları arasında her iki yıl ve popülasyonların tamamında istatistiksel bakımdan anlamlı pozitif ilişkiler belirlenirken tohum ağılığı ile meyve eni arasında 2013 yılında anlamlı ilişki olmadığı, 2014 yılında ise anlamlı ilişkiler olduğu ortaya çıkmıştır. Halep Çamı (Pinus halepensis Mill.) ağaçlandırma sahasında gerçekleştirilen çalışmada; boy, göğüs çapı ve tepe çapı ile kozalak verimi arasında istatistiksel bakımdan anlamlı $(p<0.05)$ pozitif ilişkiler belirlenmiştir (Çerçioğlu, 2013). Değişik orman ağacı türlerinde yapılan çalışmalarda da çiçek verimi arasındaki ilişkiler ağaç türü ve popülasyonlara göre farklı sonuçlar alınmıştır. Örneğin, dişi ve erkek çiçek verimi arasında Pinus brutia (Keskin, 1999; Bilir ve ark., 2002 ve 2005) ve Pinus taeda'da (Schmidtling, 1981) pozitif; Pinus eliotti (Schultz, 1971), Pinus sylvestris'te (Savolainen ve ark.,1993) negatif ilişkiler belirlenmiştir. Ancak Pinus sylvestris'te yapılan bazı çalışmalarda erkek çiçek verimi ile dişi çiçek verimi arasında pozitif ilişkiler belirlenmiştir (Bilir ve ark., 2002; 2006). Bununla birlikte, kozalak sayısı ile dolu tohum sayısı arasında Picea sitchensis (Chaisurisri ve El-Kassaby, 1993), Picea abies (Kjaer ve Wellendorf, 1997) ve Pseudotsuga menziesii'de (El-Kassaby ve Cook, 1994; Reynolds ve El-Kassaby, 1990) arasında pozitif ilişkiler belirlenmiştir. Benzer sonuçlar Bilir ve ark. (2008) tarafından üç Sarıçam tohum bahçesinde yapılan çalışmada da bulunmuştur. 

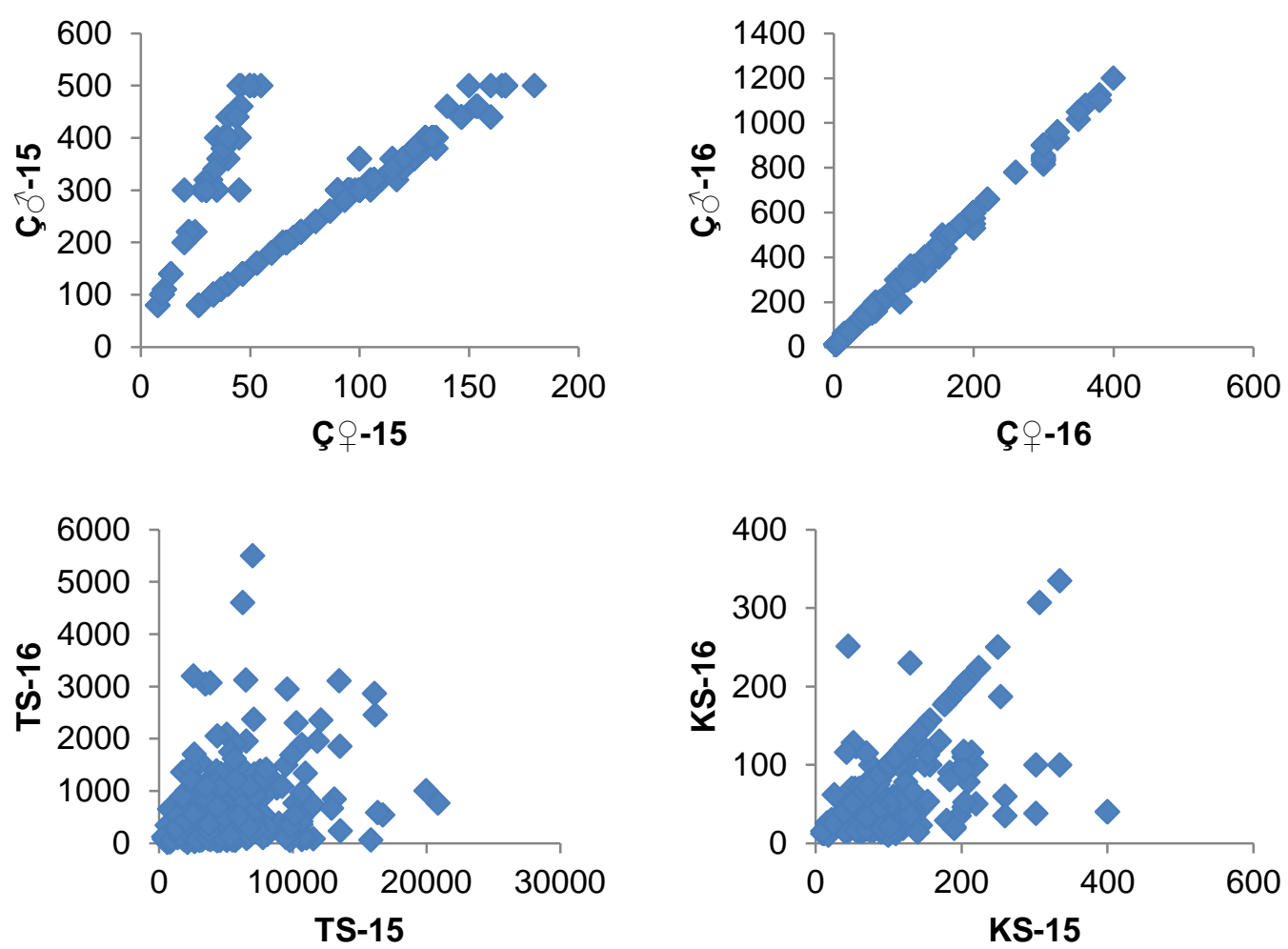

Şekil 5. Üreme özellikleri arasındaki ilişkiler

Kozalak ve tohum özellikleri üzerinde doğrudan etkili olduğu düşünülen bazı büyüme özellikleri ve yükselti ile üreme özellikleri arasındaki ilişkiler uygulanan korelasyon analizi ile belirlenerek sonuçları Tablo 6'da verilmiştir. Yaşın üreme özellikleri üzerinde istatistiksel bakımdan anlamlı ( $p>0.05)$ etkisi bulunmazken, diğer büyüme özelliklerinin üreme özelliği üzerine olan etkisi özelliklere göre değişim göstermiştir (Tablo 6). Örneğin ağaç boyunun 2015 yılı dişi çiçek verimine etkisi olmazken erkek çiçek ve 2016 yılı çiçek verimi üzerine pozitif ve anlamlı etkide bulunmuştur. Taç çapı 2015 yılı çiçek verimini pozitif 2016 yılı çiçek verimini ise negatif ve anlamlı etkilemiştir. Bununla birlikte tohum ve kozalak sayısı üzerine boy ve göğüs yüksekliği çapının daha etkili olduğu görülmektedir. Ancak üreme özellikleri üzerinde etkili olan büyüme özelliklerinin boy, taç çapı ve göğüs yüksekliği çapı şeklinde sıralandığı söylenebilir (Tablo 6). Tablo 6'dan da görüldüğü üzere 2015 yılı dişi verimi üzerine taç çapı $(r=0.31)$ ve yükselti $(r=0.66)$ istatistiksel bakımdan anlamlı $(p<0.05)$ pozitif; ağaç boyu $(r=0.14) 2016$ yılı erkek çiçek verimine istatistiksel bakımdan anlamlı $(p<0.05)$ pozitif; yine yükselti 2016 yılı dişi çiçek verimine $(r=-0.55)$ istatistiksel bakımdan anlamlı $(p<0.05)$ negatif etkide bulunmuştur. Keleş (2015), Keçiboynuzu popülasyonlarda, diğer üreme özelliklerine oranla; meyve çapı, meyve sayısı, meyve ağırlığı, tohum ağırığı ve tohum sayısının büyüme özelliklerinden daha fazla etkilendiğini belirlemiştir. Saatçioğlu (1971), bir tohum yılında besin maddelerinin büyük ölçüde harcanması ertesi yıl yetersiz tohum oluşmasına neden olabileceğini; ağaçtaki $\mathrm{C} / \mathrm{N}$ oranının artması büyük olasılıkla çiçek oluşumunu artırdığını; sıcak yazlarda toprağın kuraklığı yüzünden besin tuzlarının alımı azalır ve güneşli havalar karbonhidrat üretimini artırdığını; her yönden ışık alan ve tamamıyla serbest kalan ağaçların tepe kısımları en fazla çiçek ve meyve yaptığını belirtmektedir. Odabaşı (1990) Toros sedirinde yaşın ilerlemesi ve tepenin büyümesiyle birlikte kozalak miktarının artmasının da doğal olduğunu ifade etmektedir. Bilir ve ark. (2006) üç klonal Sarıçam tohum bahçesinde yapmış oldukları çalışmada çiçek veriminin genel olarak çok yüksek olmasa da büyüme özelliklerinden olumlu yönde etkilendiğini ve bunun özellikle dip çap ile ilişkili olduğunu belirlemişlerdir. Bhumibhamon (1978) Sarıçam'da çiçek verimi ile çap ve taç hacmi arasında pozitif ilişkiler belirlemiştir. Benzer sonuçlar Avrupa ladini'nde de belirlenmiştir (Nikkanen ve Ruotsalainen, 2000). Ancak Schmidtling (1981) tarafından doğal Pinus taeda ormanlarında çiçeklenme ile büyüme arasında negatif ilişkiler bulunmuş olup benzer sonuçlar Sarıçam'da da Nikkanen ve Velling (1987) tarafından belirlenmiştir. Bunun aksine boy ile 
çiçeklenme arasında Pinus contorta (Hannerz ve ark., korelasyonlar belirlenmiştir. 2001) ve Picea abies'te (Almqvist ve ark., 2001) düşük

Tablo 6. Büyüme özellikleri ve yükselti ile üreme özellikleri ilişkileri

\begin{tabular}{|c|c|c|c|c|c|}
\hline$r$ & B & $\mathrm{d} 1.30$ & TÇ & Y & $\mathrm{R}$ \\
\hline $\mathbf{C}+15$ & $-.03 N S$ & $-.03 \mathrm{NS}$ & .31 & $-.04 N S$ & .66 \\
\hline Ç & .17 & $.11 \mathrm{NS}$ & .13 & $.04 N S$ & $-.01 \mathrm{NS}$ \\
\hline$C{ }_{+}-16$ & .14 & $-.04 N S$ & -.14 & $-.03 \mathrm{NS}$ & -.55 \\
\hline Ç-16 & .14 & $-.04 \mathrm{NS}$ & -.14 & $-.03 \mathrm{NS}$ & -.55 \\
\hline TS-15 & . 17 & .17 & $.09 N S$ & $.05 \mathrm{NS}$ & $-.08 \mathrm{NS}$ \\
\hline TB-15 & .38 & $.02 \mathrm{NS}$ & .59 & $.02 N S$ & .67 \\
\hline TE-15 & .37 & $-.02 \mathrm{NS}$ & .60 & $-.04 N S$ & .76 \\
\hline TA-15 & .22 & .17 & .16 & $.07 \mathrm{NS}$ & $-.01 \mathrm{NS}$ \\
\hline TS-16 & .14 & $.04 N S$ & .24 & $.02 N S$ & .19 \\
\hline TB-16 & .38 & $.0 N S$ & .59 & $-.01 \mathrm{NS}$ & .67 \\
\hline TE-16 & .37 & $-.02 \mathrm{NS}$ & .60 & $-.04 N S$ & .76 \\
\hline TA-16 & .16 & .47 & .26 & $-.07 \mathrm{NS}$ & .21 \\
\hline KS-15 & .13 & .15 & $.08 \mathrm{NS}$ & $.02 N S$ & $-.08 N S$ \\
\hline KB-15 & .48 & $.02 N S$ & .45 & $-.01 \mathrm{NS}$ & .25 \\
\hline KE-15 & .44 & $-.03 N S$ & .28 & $-.01 \mathrm{NS}$ & $.07 N S$ \\
\hline KA-15 & .51 & $.01 \mathrm{NS}$ & .40 & $-.04 \mathrm{NS}$ & $.07 \mathrm{NS}$ \\
\hline KS-16 & $.06 \mathrm{NS}$ & $.01 \mathrm{NS}$ & $.05 \mathrm{NS}$ & $-.03 N S$ & -.17 \\
\hline KB-16 & .48 & $.01 \mathrm{NS}$ & .45 & $-.01 \mathrm{NS}$ & .25 \\
\hline KE-16 & .44 & $-.03 N S$ & .28 & $-.01 \mathrm{NS}$ & $.07 N S$ \\
\hline KA-16 & .53 & $.01 \mathrm{NS}$ & .41 & $-.01 \mathrm{NS}$ & $.07 N S$ \\
\hline
\end{tabular}

NS; ilişkiler istatistiksel bakımdan anlamlı değildir.

Doğal Toros Göknarı (Abies cilicica Carr.) popülasyonlarında gerçekleştirilen çalışmada, boy ile kozalak verimi arasında istatistiksel bakımdan anlamlı ilişki bulunamazken ( $p \geq 0.05$ ); göğüs çapı, yaş ve tepe çapı arasında istatistiksel bakımdan anlamlı $(p \leq 0.05)$ pozitif ilişki belirlenmiştir (Ülküdür, 2013). Boydak (1977) Sarıçam'ın doğal meşcerelerinde yapmış olduğu çalışmada, tohum veriminin 41-60 yaşlarında düşük, 81-100 yaşlarında en yüksek ve 181-200 yaşlarında düşük olduğunu belirlemiştir. Prescher ve ark. (2007) Sarıçam'ın tohum bahçesinde yapmış oldukları çalışmada, yaş ile kozalak verimi arasında önemli ilişkiler belirlerken $(r=0.675, p<0.05)$; yaşın tohum verimini $(r=0.59$, $p>0.05)$ etkilemediğini belirlemişlerdir. Boydak (1977) doğal sarıçam meşcerelerinde yapmış olduğu çalışmada göğüs çapı ile tohum verimi arasında pozitif ilişki olduğunu; aynı türde Bhumibhamon (1978) çiçek verimi ile tepe çapı arasında pozitif ilişki olduğunu belirlerken, Nikkanen ve Velling (1987) türün doğal meşcerele- rinde büyüme ile çiçek verimi arasında negatif ilişki belirlemişlerdir. Bilir ve ark., (2008) sarıçam tohum bahçelerinde genel olarak çiçek verimi ile ağaç boyutu arasında pozitif ilişki olduğunu belirtmişlerdir.

Bilir ve ark. (2017a), Akdeniz servisinin (Cupressus sempervirens L.) plantasyon sahasında gerçekleştirmiş oldukları çalışmada boy ve çapın kozalak verimi üzerinde pozitif ve anlamlı $(p \leq 0.05, r>0.29)$ etkisinin olduğunu belirlemişlerdir. Eler (1990) doğal Kızılçam popülasyonlarında yapmış olduğu çalışmada, yaş ve yükseltinin tohum yılını etkilediğini belirlemiştir. Bu sonuçlara ek olarak, birçok genetik ve çevre faktörlerinin çiçek, kozalak ve tohum verimi üzerine etkisi olduğu değişik orman ağacı türlerinde belirlenmiştir (Boydak, 1977; Koski, 1991; Mátyás, 1991; Eriksson, 2008). Toros Göknarı'nın (Abies cilicica Carr.) rakımsal olarak örneklenen popülasyonlarında gerçekleştirilen çalışma sonucunda, yükselti ile kozalak verimi arasında istatis- 
tiksel bakımdan $(p \leq 0.05)$ anlamlı ve negatif $(r=-0.350)$ ilişkiler bulunmuştur (Ülküdür, 2013). Ehrami Karaçam (Pinus nigra Arnold. subsp. pallasiana var. pyramidata) ağaçlandırma sahalarında yapılan çalışmada ağaç boyu ve göğüs yüksekliği çapının kozalak verimini pozitif olarak ve anlamlı etkilediği belirlenmiştir (Bilir ve ark., 2017b). Ailelerin örneklendiği yükseltinin üreme özellikleri üzerine olan etkisi ise özelliklere göre değişim göstermiştir (Tablo 6). Örneğin yükseltinin 2015 yılı erkek çiçek verimine etkisi olmazken dişi çiçek verimi üzerine pozitif, 2016 yılı çiçek verimi üzerine ise negatif ve anlamlı etkide bulunmuştur (Tablo 6). Gerek çalışmamızda ve gerekse önceki çalışmalarda elde edilen sonuçlar türün tohum kaynaklarının seleksiyon, bakım ve ıslahı ile kaliteli tohum üretim çalışmaları için önem arz etmektedir.

\section{TEŞEKKÜR}

Bu çalışma, Prof. Dr. Nebi Bilir danışmanlığında tamamlanan doktora tez çalışmasının bir bölümünü içermektedir. Çalışmamızı 4466-D1-15 nolu proje kapsamında maddi olarak destekleyen Süleyman Demirel Üniversitesi Bilimsel Araştırma Projeleri Yönetim Birimi Başkanlığı ve çalışanlarına teşekkür ederiz.

\section{KAYNAKLAR}

Almqvist, C., Jansson, G., Sonesson, J., (2001). Genotypic Correlations between Early Cone-Set and Height Growth in Picea abies Clonal Trials. Forest Genetics, 8:197-204.

Alptekin, C.Ü. (1986). Anadolu Karaçamı [Pinus nigra Arn. ssp. Pallasiana (Lamb.) Holmboe]'nin Coğrafik Varyasyonları. İstanbul Üniversitesi, Orman Fakültesi Dergisi, $36: 132-154$.

Anonim (1986). Fidanlık Çalışmaları. Orman Genel Müdürlüğü Yayınları, 168s., Ankara.

Anonim (2017). Orman varlığımız. TC. Çevre ve Orman Bakanlığı Orman Genel Müdürlüğü, $28 \mathrm{~s}$, Ankara.

Ata, C. (1995). Silvikültür Tekniği. Zonguldak Karaelmas Üniversitesi Bartın Orman Fakültesi. Yayın No: 465 Bartın.

Bhumibhamon, S. (1978). Studies on Scots pine Seed Orchards in Finland with Special Emphasis on the Genetic Composition of the Seed. Comm Inst For Fenn, 94:1-118.

Bila, A. D., Lindgren, D. (1998). Fertility variation in Milletia sthuhlmannii, Brachystegia spiciformis, Brachystegia bohemii and Leucaena leucocephala and Its Effects on Relatedness in Seeds. Forest Genetics, 5:119-129.

Bila, A. D., Lindgren, D., Mullin, T.J. (1999). Fertility Variation and Its Effect on Diversity over Generations in a Teak Plantation (Tectonia grandis L.f.). Silvae Genetica, 48:109-114.

Bila, A. D. (2000). Fertility Variation and Its Effects on Gene Diversity in Forest Tree Populations. Ph.D. Thesis. Swedish University of Agricultural Science,. Acta Universitatis Agriculturae Sueciae, Silvestria 166, Umeå, Sweden, pp. 31.

Bilir, N., Kang, K.S., Ozturk, H. (2002). Fertility Variation and Gene Diversity in Clonal Seed Orchards of Pinus brutia,
Pinus nigra and Pinus sylvestris in Turkey. Silvae Genetica, 51:112-115.

Bilir, N., Kang, K. S., Lindgren, D. (2005). Fertility Variation in Six Populations of Brutian pine (Pinus brutia Ten.) Over Altitudinal Ranges, Euphtyica, 141:163-168.

Bilir, N., Prescher, F., Ayan, S., Lindgren, D. (2006). Growth Characters and Number of Strobili in Clonal Seed Orchards of Pinus sylvestris. Euphytica, 152:293-301.

Bilir, N., Prescher, F., Lindgren, D., Kroon, J. (2008). Variation in Seed Related Characters in Clonal Seed Orchards of Pinus sylvestris, New Forests, 36:187-199.

Bilir, N. (2017). Cone Production Variation in a Clonal Seed Orchard of Scots Pine (Pinus sylvestris). Seed Orchard Conference, Balsta, Sweden, 4-6 September. pp. 49.

Bilir, N., Cercioglu, M., Cetinkaya, D. (2017a). Interaction Between Cone Production and Growth Traits in a Mediterranean Cypress (Cupressus sempervirens L.) Plantation. Seed Orchard Conference-2017, Balsta, Sweden, 4-6 September. pp. 64.

Bilir, N., Çatal, Y., Tekocak, S., Cercioglu, M. (2017b). Fertility Variation in Endemic Populations of Ehrami Black Pine (Pinus nigra Arnold. subsp. pallasiana var. pyramidata). Journal of Forestry Reserch, 28(4), 683-686.

Bilir, N., Özel, H.B. (2017b). Fertility Variation in a Natural Stand of Taurus Cedar (Cedrus libani A. Rich.). International Forestry and Environment Symposium (IFES), 7-10 November, Trabzon, p.201.

Bilir, N., Özel, H.B. (2017a). Variation in Strobili and Cone Production among Clones in a Pinus nigra Seed Orchard. The International Conference on Agriculture, Forest, Food Sciences and Technologies (ICAFOF). Cappadocia, May $15-17$, p. 798.

Boydak, M. (1977). Eskişehir-Çatacık Mıntıkası Ormanlarında Sarıçam (Pinus silvestris L.)'ın Tohum Verimi Üzerine Araştırmalar, İstanbul Üniversitesi Orman Fakültesi Yayınları, İstanbul. 25 (1):15-234.

Chaisurisri, K., El-Kassaby, Y. A. (1993). Estimation of Clonal Contribution to cone and Seed Crops in a Sitka Spruce Seed Orchard. Annales Science of Forestry, 50: 461467.

Çerçioğlu, M. (2013). Osmaniye Yöresi Halep Çamı (Pinus halepensis Mill.) Populasyonlarında Kozalak Verimi. Süleyman Demirel Üniversitesi Fen Bilimleri Enstitüsü. Yüksek Lisans tezi. 42s, Isparta.

Eler, Ü. (1990). Kızılçamda (Pinus brutia Ten.) Yaşa Bağlı Olarak Tohum Verimi. Batı Akdeniz Ormancılık Araştırma Enstitüsü, Teknik Bülten. 225, Antalya, $78 \mathrm{~s}$.

El-Kassaby, Y. A., Cook, C. (1994). Female Reproductive Energy and Reproductive Success in a Douglas-fir Seed Orchard and Its Impact on Genetic Diversity. Silvae Genetica, 43:243-246.

El-Kassaby, Y. A. (1995). Evaluation of Tree-Improvement Delivery System: Factors Affecting Genetical Potential. Tree Physiology, 15:545-550.

Eriksson, G. (2008). Pinus sylvestris Resent Genetic Research. SLU Genetic Center, 111 p., Uppsala.

Gaussen, H., Heywood, V.H., Cheter, A.O. (1964). The Genus Pinus in Flora of Eoropea, Vol.I, Camridge, $670 \mathrm{~s}$.

Griffin, A. R. (1982). Clonal Variation in Radiata pine Seed Orchard, Some Flowering, Cone and Seed Production Traits, Australian Forest Research, 12:295-302. 
Hannerz, M., Aitken, S., Ericsson, T., Ying, CC. (2001). Inheritance of Strobili Production and Genetic Correlation with Growth in Lodge pole pine, Forest Genetics, 8:323-329.

Kang, K. S., Lindgren, D., 1998. Fertility Variation and Its Effect on the Relatedness of Seeds in Pinus densiflora, Pinus thunbergii and Pinus koraiensis Clonal Seed Orchards. Silvae Genetica, 47:196-201.

Kang, K. S. (2001). Genetic Gain and Gene Diversity of Seed Orchard Crops. Ph.D Thesis. Swedish University of Agricultural Science, Acta Universitatis Agriculturae Sueciae, Silvestria 187, Umeå, Sweden, pp.75.

Kang, K. S., Bila, A. D., Harju A. M., Lindgren D. (2003). Fertility Variation in Forest Tree Populations, Forestry, 76:329-344.

Keleş, H. (2015). Mersin Yöresi Keçiboynuzu (Ceratonia siliqua L.) Popülasyonlarında Tohum-Meyve Verimi ile Büyüme Özellikleri Etkileşimi. Süleyman Demirel Üniversitesi Fen Bilimleri Enstitüsü. Doktora tezi. 82s, Isparta.

Keskin, S. (1999). Çameli-Göldağı Orijinli Kızılçam Tohum Bahçesinde Çiçek ve Kozalak Verimi Açısından Klonal Farklılıklar ve Çiçeklenme Fenolojisi. Batı Akdeniz Ormancılık Araştırma Enst., 9, 96 s., Antalya.

Kjaer, ED. (1996). Estimation of Effective Population Number in a Picea abies Seed Orchard Based on Flower Assessment. Scandinavian Journal of Forest Research, 11:111121.

Kjaer, E.D., Wellendorf, H. (1997). Variation in Flowering and Reproductive Success in a Danish Picea abies (Karst) Seed Orchard. Forest Genetics, 4:181-188.

Koski, V. (1991). Genereative Reproduction and Genetic Process in Nature. In: Mátyás C (ed) Genetics of scots pine. Elsevier publishers, pp 59-72, Amsterdam.

Mátyás, C. (1991). Seed Orchards. In: Mátyás C (ed) Genetics of Scots pine. Elsevier publishers, Amsterdam, pp 5972.

Nikkanen, T., Velling, P. (1987). Correlations Between Flowering and Some Vegetative Characteristics of Grafts of Pinus sylvestris, Forest Ecology and Management, 19:3540.

Nikkanen, T., Ruotsalainen, S. (2000). Variation in Flowering Abundance and Impact on the Genetic Diversity of the Seed Crop in a Norway Spruce Seed Orchard. Silva Fennica, 34:205-222.

Odabaşı, T. (1990). Lübnan Sediri (Cedrus libani A. Rich.)'nin Kozalak ve Tohumu Üzerine Araştırmalar, Orman Genel Müdürlüğü Yayınları, Ankara, 133 s.

Özdamar, K. (1999). Paket Programlar İle İstatistiksel Veri Analizi, Kaan Kitabevi, Eskişehir.
Prescher, F, Lindgren, D., Almqvist, C., Kroon, J., Lestander, T.A., Mullin, T. (2007). Female Fertility Variation in Mature Pinus sylvetris Clonal Seed Orchards. Scandinavian J. Forest Research, 22:280-289.

Reynolds, S., El-Kassaby, Y.A. (1990). Parental Balance in Douglas-fir Seed Orchards-Cone Crop vs. Seed Crop. Silvae Genetica, 39:40-42.

Saatçioğlu, F. (1971). Orman Bakımı. İstanbul Üniversitesi Orman Fakültesi Yayınları, 1636/160, Sermet Matbaası, 303 s. İstanbul.

Savolainen, O., Karkkainen, K., Harju, A., Nikkanen, T., Rusanen, M. (1993). Fertility Variation in Pinus sylvestris: a Test of Sexual Allocation Theory, Amererican Journal of Botany, 80:1016-1020.

Schmidtling, R. C. (1981). The Inheritance of Precocity and Its Relationship with Growth in Loblolly pine. Silvae Genetica, 30:188-192.

Schultz, R.P. (1971). Stimulation of Flower and Seed Production in a Young Slash Pine Orchard. U.S. Southeastern For. Exp. Station. USDA Forest Service, SE-91, 10p., USA.

Shea, K. L. (1987). Effects of Population Structure and Cone Production on Out Crossing Rates in Engelmann spruce and Subalpine fir. Evolution, 41:124-136.

Uysal, Çelik, S. (2015). Sütçüler-Tota Orijinli Gönen Karaçam Tohum Bahçesinde Kozalak ve Tohum Özellikleri Bakımından Klonal Varyasyon. Süleyman Demirel Üniversitesi Fen Bilimleri Enstitüsü. Doktora tezi. 109, Isparta.

Ülküdür, F. (2013). Seydişehir yöresi Toros Göknarı (Abies cilicica Carr.) popülasyonlarında kozalak verimi. Süleyman Demirel Üniversitesi Fen Bilimleri Enstitüsü. Yüksek Lisans tezi. 44s, Isparta.

Ürgenç, S. (1967). Türkiye'de Çam Türlerinde Tohum Tedarikine Esas Teşkil Eden Problemlere Ait Araştırmalar. Orman Genel Müdürlüğü Yayınları, 44s, Ankara.

Xie, C. Y., Knowles, P. (1992). Male Fertility Variation in an Open-pollinated Plantation of Norway spruce (Picea abies). Canadian Journal of Forest Research, 22:14631468.

Yaltırık, F. (1993). Dendroloji-I, Gymnospermae (Açık Tohumlular). İ. Ü. Orman Fakültesi Yayınları, 320s, İstanbul.

Yazıcı, N., Bilir, N. (2017). Aspectual Fertility Variation and Its Effect on Gene Diversity of Seeds in Natural Stands of Taurus Cedar (Cedrus libani A. Rich.). International Journal of Genomics, 2960624:1-5.

Zobel, B., Talbert, J. (1984). Applied forest tree improvement. John Wiley \& Sons, pp 505, New York. 